\title{
TEMPORAL CHANGES OF AQUATIC MACROPHYTES VEGETATION IN A LOWLAND GROUNDWATER FEED EUTROPHIC COURSE (KLÁTOVSKÉ RAMENO, SLOVAKIA)
}

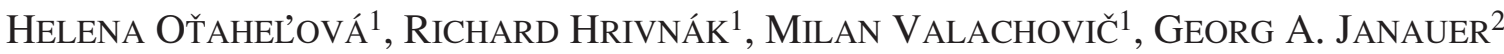 \\ ${ }^{1}$ Institute of Botany, Slovak Academy of Sciences \\ Dúbravská cesta 14, SK-845 23 Bratislava, Slovak Republic \\ e-mail: helena.otahelova@savba.sk \\ ${ }^{2}$ Institute of Ecology and Conservation Biology, University of Vienna \\ Althanstrasse 14, A-1090, Wien, Austria
}

(Received: April 10, 2006. Accepted: November 15, 2006)

\begin{abstract}
Klátovské rameno is the lowland slow-flowing groundwater feed eutrophic tributary of the Malý Dunaj River (Danube Plain), where our study of temporal changes of aquatic macrophytes vegetation was realised in 1999 and 2005. For survey of aquatic vascular macrophytes the Kohler's method (Janauer 2003) was used, which is compliant with European standard EN 14184. Altogether 35 aquatic macrophyte species were recorded during the survey. Nuphar lutea persisted as the most dominant species in 1996 and 2005. Species diversity increased slightly after the nine years: ten species immigrated to the watercourse. The changes in species abundance have shown weak differences, however the abundance of Sparganium emersum has increased markedly. Alien species Elodea canadensis and both S. emersum and Hydrocharis morsus-ranae significantly enlarged their distribution in the stream. The ecological quality of the river, based on the aquatic macrophytes assessment criteria, was slightly impaired after nine years, but still $90 \%$ of its studied course has a high or good ecological status.
\end{abstract}

KEY WORDS: aquatic plants, diversity, distribution, lowland eutrophic stream, ecological status WFD.

\section{INTRODUCTION}

Lowland watercourses in Europe belong probably to water bodies most heavily and long-lastingly altered by man. The Danube lowland in Slovakia, for instance, is interlaced by a network of relic watercourses, which have transferred to almost terrestrial conditions due to succession processes (Pišút et al. 2004). Watercourses have been stabilized by embankments and they are very often canalised, and mutually interlinked by a network of artificial canals. The running waters have long been engineered to drain the surrounding land more efficiently; and original river channels have been re-directed. Changes in hydro-morphological and physicochemical characteristics of water-bodies are reflected in the biotic sphere. The changes detected in the study period provided new information on processes related to the diversity of species and enhanced our possibility to use this knowledge in the socio-economical context.

Data on floristic composition and distribution of macrophytes are essential for understanding the aquatic ecosystems behaviour (Haslam 1978; Wiegleb 1981; Robach et al. 1996; Baattrup-Pedersen and Riis 1999; Thiébaut and Muller 1999; Bernez et al. 2004; Demars and Harper 1998, 2005). The European Water Framework Directive (WFD, Council of European Communities 2000) calls for the asses- sment of the ecological status and for monitoring water-bodies by use of biological indicators, including the macrophytes. This assessment is based on taxonomic composition, and abundance of aquatic macrophytes is currently under progress in many countries (Schaumburg et al. 2004; Dodkin et al. 2005; Meilinger et al 2005; Onaindia et al. 2005).

The distribution and abundance of macrophytes in the running waters of Slovakia, the majority of which are related to the Danube watershed, have already been described in relation to some relevant environmental factors or the management (Hrivnák et al. 2003, 2004; Ot’ahelová and Valachovič 2003; Janauer and Exler 2004; Jursa and Ot’ahelová 2005; Ot’ahelová and Banásová 2005). WFD requirements oblige us to define specific reference conditions of the ecological status for specific water-body types. As their majority is already modified by man, it is difficult to specify the respective environmental conditions.

The Klátovské rameno stream, a tributary to Maly Dunaj (Little Danube) River, is a rarity in the agriculturally modified landscape of the Danube lowland. Its reach was included in the list of NATURA 2000 habitats. This decision was based on its high diversity of aquatic and wetland biota (Holčík 2004; Szabóová and Bankó 2004), making it the stream of choice for a repetition of our aquatic macrophyte survey. 
Our aim was to define and compare the changes in species distribution, abundance and diversity of aquatic macrophytes in the lowland slow-flowing, groundwater-fed eutrophic river Klátovské rameno, nine years after the last survey. With respect to the monitoring needs of the WFD and considering the river's natural and unique character, the "ecological status" in the sense of the WFD was assessed for the "biological element macrophytes".

\section{MATERIAL AND METHODS}

\section{Study area}

Klátovské rameno stream is a relatively short (approximately $30 \mathrm{~km}$ ) right-hand tributary of Malý Dunaj R., located in the Danubian Plain between the main channel of the Danube R. in the south, and the Malý Dunaj R. in the north (Fig. 1). The entire area is currently controled by dams, and the excess seepage water is caught by a network of drainage canals. Due to this situation the catchment of Klátovské rameno stream is free from spates or flood run-off.

Due to intensive groundwater connection the hydrology of Klátovské rameno stream depends on the run-off regime of the Malý Dunaj R. (Šimo and Zat'ko 2002); Mean monthly discharge was $3.416 \mathrm{~m}^{3} . \mathrm{s}^{-1}$ in Trhová Hradská hydrogauge station in the year 1999 (by Slovak Hydrometeorologic Institute). The climate in the Malý Dunaj catchment is warm (July mean temperature is above $20^{\circ} \mathrm{C}$ ) and very dry (mean annual precipitation totals from 500 to $550 \mathrm{~mm}$ ) and winters are mild (Lapin et al. 2002).

The lowland landscape is typical for intensively cultivated agricultural land. Despite this, the rests of the willowpoplar floodplain forests still exist along the Klátovské rameno stream (Michalko et al. 1987).

Forest, water, and swamp biotopes, with rare plant and animal species are controled in a National Nature Reserve since 1993, and; in addition, the establishment of the Site of Community Importance (SCI) in the framework of the NATURA 2000 has been proposed.

Data were obtained in the middle reach of the water-body between the Dunajský Klatov village (48 $01^{\prime} 54.2^{\prime}$ ' $\mathrm{N}$; $17^{\circ} 41^{\prime} 08.5^{\prime}$ ' E, $112 \mathrm{~m}$ a.s.1.) upstream and the confluence of the Klátovské rameno stream with its right tributary the Gabčíkovo-Topolníky canal near the Trhová Hradská village (47 59'03.3' ' N; 1746'25.8', E, $108.9 \mathrm{~m}$ a.s.1.) downstream. The total length of the watercourse $(11.5 \mathrm{~km})$ was surveyed. The upper three survey units were situated in the canalised Klátovský canal (1.8 km in length). The banks are stabilized, and the width of the bed is $8-9 \mathrm{~m}$. Maximum depth was $160 \mathrm{~cm}$ during the survey, and the Secchi transparency was $65-120 \mathrm{~cm}$. In the following units of the Klátovské rameno stream (approximately $9.5 \mathrm{~km}$ ) the channel is natural, meandering, locally braided, and 25-90 $\mathrm{m}$ wide. Flow velocity is low, accelerating to medium only near bridges. Different lentic microhabitats occurred along the banks. Depth of the stream channel varied between 150 $\mathrm{cm}$ in many parts, but depth of more than $200 \mathrm{~cm}$ was found quite often. The seepage water in the stream is rather cool, highly transparent, and the bottom is often visible. Fine substrate prevails in the banks and in the riverbed. Bank morphology of Klátovské rameno stream is of homogeneous character, apart from the sites adjacent to bridges. Despite the fact that extensively utilized farmland lines the banks, the floodplain forest forms an almost continuous braid along the river course. The two small villages Dunajský Klatov and Trhová Hradská are closely situated to the surveyed reaches. Information on selected environmental variables is presented in the Table 1 .

\section{Sampling procedure}

The field surveys were carried out in July 1996 and in July 2005, using a boat. The survey method follows the European Standard EN 14184 (2003) which is based on the procedure described by Kohler (Kohler 1978; Kohler and

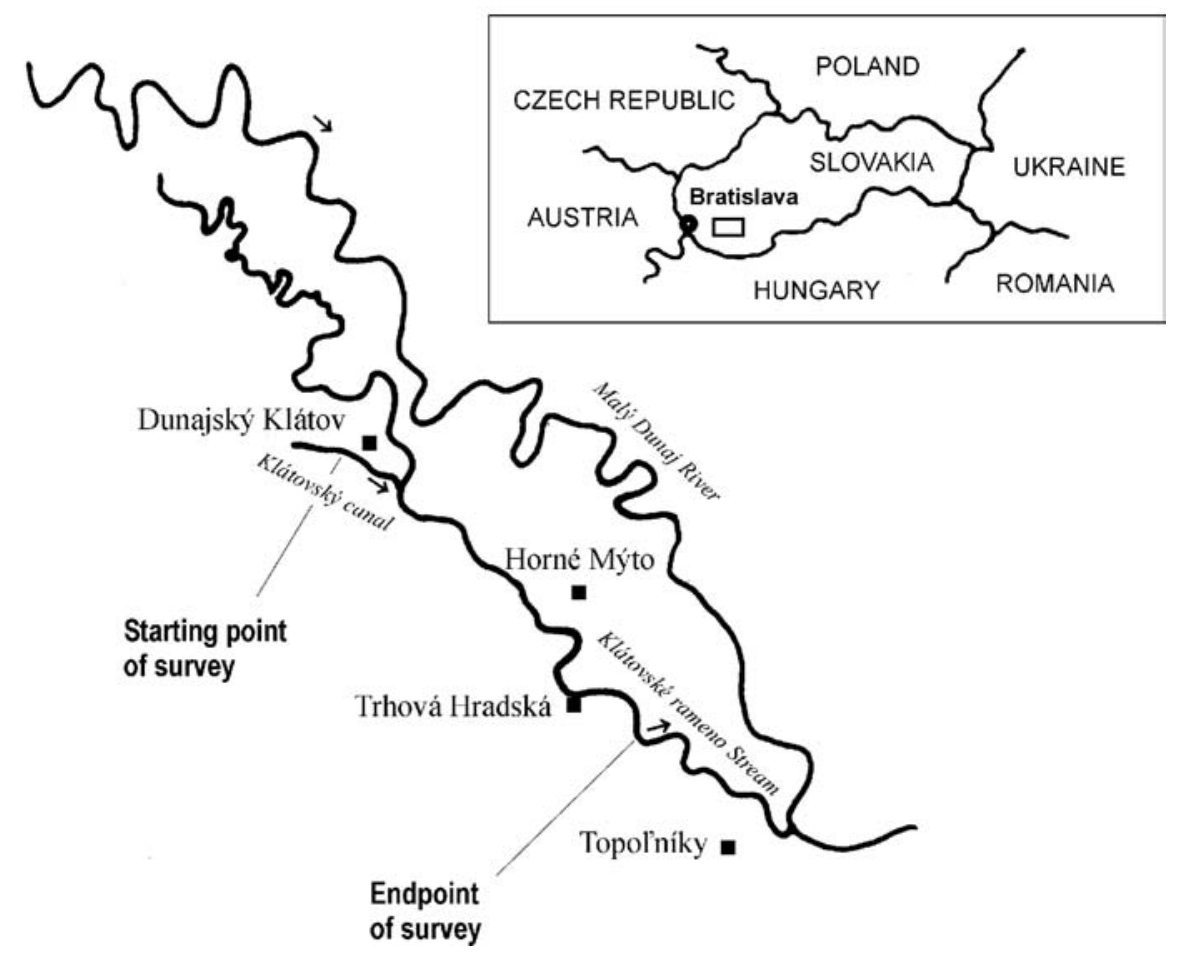

Fig. 1. Location of the study area. 
TABLE 1. Characteristics of environmental variables (data from 2005).

\begin{tabular}{|c|c|c|c|c|c|}
\hline Characteristics & Units & Mean & Max & Min & SD \\
\hline Width of the channel & $\mathrm{m}$ & 39.3 & 90.0 & 8.0 & . \\
\hline Conductivity of water & $\mu \mathrm{S} . \mathrm{cm}^{-1}$ & 618.89 & 639.90 & 595.87 & 18.71 \\
\hline $\mathrm{pH}$ of the water & & 7.85 & 7.94 & 7.80 & 0.50 \\
\hline Temperature of water & degree $\mathrm{C}$ & 17.30 & 18.20 & 15.90 & 0.89 \\
\hline Cover of macrophytes & $\%$ & 46 & 90 & 5 & . \\
\hline \multirow[t]{2}{*}{ Bank structure* } & Category & $1 / 2$ & 4 & & \\
\hline & $\%$ & 0.4 & 99.6 & & \\
\hline \multirow[t]{2}{*}{ Bed material* } & Category & $1 / 2$ & 2 & $2 / 4$ & 4 \\
\hline & $\%$ & 0.4 & 15.9 & 52.8 & 30.9 \\
\hline \multirow[t]{2}{*}{ Flow class* } & Category & 2 & 3 & & \\
\hline & $\%$ & 96.1 & 3.9 & & \\
\hline \multirow[t]{2}{*}{ Land use type* } & Category & 1 & 2 & $3 / 2$ & 3 \\
\hline & $\%$ & 8.3 & 12.3 & 22.8 & 56.6 \\
\hline
\end{tabular}

Total length of survey units in $\mathrm{m}$

11336.0

* Bank structure and bed material: 1 - bank protection; 2 - gravel; 4 - fine substrate

* Flow class: 2 - low flow; 3 - medium velocity

* Land use: 1 - settlement; 2 - agricultural land; 3 - broad leaved forest

TABLE 2. Species composition, growth forms (GF), groups of ecological quality (Gr), and the categories of threat in the Klátovské rameno watercourse in 1996 and 2005

\begin{tabular}{|c|c|c|c|c|c|c|}
\hline Taxon & Abbreviation & 1996 & 2005 & GF & $\mathrm{Gr}$ & Threat \\
\hline Alisma plantago-aquatica & Ali pla & & & $\mathrm{Am}$ & B & \\
\hline Batrachium circinatum & Bat cir & & & $\mathrm{Sa}$ & B & \\
\hline Batrachium trichophyllum & Bat tri & & & $\mathrm{Sa}$ & B & \\
\hline Berula erecta & Ber ere & & & Am & A & VU \\
\hline Butomus umbellatus & But umb & & & Am & B & VU \\
\hline Callitriche sp. & Cal sp. & & & $\mathrm{Fl}$ & A & \\
\hline Ceratophyllum demersum & Cer dem & & & $\mathrm{Sa}$ & B & \\
\hline Elodea canadensis & Elo can & & & $\mathrm{Sa}$ & $\mathrm{C}$ & \\
\hline Groenlandia densa & Gro den & & & $\mathrm{Sa}$ & A & $\S \mathrm{EN}$ \\
\hline Hippuris vulgaris & Hip vul & & & $\mathrm{Sa}$ & A & $\S \mathrm{EN}$ \\
\hline Hydrocharis morsus-ranae & Hyd mor & & & Ap & B & \\
\hline Iris pseudacorus & Iri pse & & & $\mathrm{Am}$ & B & \\
\hline Lemna minor & Lem min & & & Ap & B & \\
\hline Lemna trisulca & Lem tri & & & $\mathrm{Sp}$ & B & \\
\hline Myosotis scorpioides & Myo sco & & & $\mathrm{Am}$ & A & \\
\hline Myriophyllum spicatum & Myr spi & & & $\mathrm{Sa}$ & B & \\
\hline Myriophyllum verticillatum & Myr ver & & & $\mathrm{Sa}$ & B & $\S \mathrm{VU}$ \\
\hline Najas marina & Naj mar & & & $\mathrm{Sa}$ & B & LR \\
\hline Nuphar lutea & Nup lut & & & $\mathrm{Fl}$ & A & $\S \mathrm{VU}$ \\
\hline Nymphaea alba & Nym alb & & $*$ & $\mathrm{Fl}$ & A & $\S \mathrm{VU}$ \\
\hline Potamogeton crispus & Pot cri & & & $\mathrm{Sa}$ & B & \\
\hline Potamogeton lucens & Pot luc & & & $\mathrm{Sa}$ & B & \\
\hline Potamogeton pectinatus & Pot pec & & & $\mathrm{Sa}$ & B & \\
\hline Potamogeton perfoliatus & Pot per & & & $\mathrm{Sa}$ & A & LR \\
\hline Potamogeton pusillus & Pot pus & & & $\mathrm{Sa}$ & B & \\
\hline Rorippa amphibia & Ror amp & & & Am & A & \\
\hline Sagittaria sagittifolia & Sag sag & & & $\mathrm{Fl}$ & A & LR \\
\hline Schoenoplectus lacustris & Sch lac & & & Am & B & \\
\hline Sparganium emersum & Spa eme & & & $\mathrm{Fl}$ & B & \\
\hline Sparganium erectum & Spa ere & & & $\mathrm{Am}$ & B & \\
\hline Spirodela polyrhiza & Spi pol & & & Ap & B & \\
\hline Typha angustifolia & Typ ang & & & Am & B & \\
\hline Typha latifolia & Typ lat & & & $\mathrm{Am}$ & B & \\
\hline Veronica anagallis-aquatica & Ver ana & & & Am & A & \\
\hline Zannichellia palustris & Zan pal & & & $\mathrm{Sa}$ & $\mathrm{C}$ & \\
\hline
\end{tabular}

Abbreviations: GF: Am - amphiphytes; Ap - acro-pleustophytes; Fl - floating leaf rhizophytes; Sa - submersed anchored macrophytes; Sp - submersed pleustophytes; Gr: explain in text (Material and Methods).

Threat: EN - endangered; LR - lower risk; VU - vulnerable; $\S$ - protected by law; * recorded beyond the time of the field survey.

Janauer 1995; Janauer 2003). Occurrence and abundance of aquatic macrophytes were assessed in contiguous survey units (SU) comprising ecologically uniform units (21 SU in
1996, and 18 SU in 2005). The exact locations of start- and endpoints of the SU, measured in 2005 using the GPS, were marked in a topographic map (scale 1:25 000). 
In each survey unit the macrophyte abundance was estimated using a five-level scale (EN 14184, 2003) expressed as Plant Mass Index (PME). The total cover of all aquatic plants, and some selected environmental variables such as bank structure, bed material, flow class, the CORINE land use class (Janauer 2003), and the width of the channel were assessed only in 2005. The WTW pH/Cond 340i device in five sites along the watercourse measured hydro-chemical parameters such as electric conductivity, $\mathrm{pH}$, and water temperature in 2005 .

\section{Data analysis}

Based on the field data, a species list was compiled, comprising species abbreviations, growth form categories (GF), and groups of ecological quality (Gr, Table 2). The PME field data were used to create the Distribution Diagrams and to calculate numerical derivates, Relative Plant Mass (RPM), Mean Mass Total (MMT), and the Distribution Ratio (d) indices (Janauer 2003). This procedure is used by a majority of the Danube countries. Distribution diagrams, numerical derivates, and abiotic parameters were produced on-line via the www. midcc. at web-site.

The PME data were also used to compute the Shannon species diversity index $H_{s}$ (Whittaker 1972). Floristic similarity was calculated with the Sørensen index $I S_{s}$ (Sørensen 1948).

CANOCO 4.5 for Windows package (ter Braak and Šmilauer 2002) was used for running Principal Components Analysis (PCA). The length of gradient for the first axis in Detrended Correspondence Analysis (DCA) was 1.805 (1996) and 2.407 (2005), respectively, indicating that the linear model was suitable for the analysis.

The ecological status of Klátovské rameno (in the sense of WFD 2000) was assessed for the macrophytes. The reference index $(R I)$ of aquatic plants was transformed into a scale from 0 to 1 and expressed as the Module macrophytes $\left(M_{M P}\right)$. This value was calculated for each SU accor- ding to Schaumburg et al. (2004). Both hydrophytic and amphiphytic species, which grew in the aquatic environment were taken into consideration. The RI was not defined, if only a single species had been recorded in a SU (12 $\mathrm{SU}$ in 1996). A species categorization to the group of ecological quality (Table 2, column Gr: A - species of reference conditions, $\mathrm{B}-$ species \pm indifferent to environment, $\mathrm{C}$ - alien species and indicators of disturbed environment) was performed addressing the already obtained phytosociological experience in Slovakia (Ot’ahelová 1995a, b; Ot’ahelová et al. 2001; Hrivnák 2002a, b).

The WFD has specified a five level scale of the ecological quality status ranging from "high", "good", "moderate", "poor" and "bad". The classification of the ecological status categories of the studied watercourse was based on the $M_{M P}$ value: the $\mathrm{M}_{M P}>0.6$ defines a High Status, the $\mathrm{M}_{M P}=0.51-0.6-\mathrm{a}$ Good Status. If in a certain SU the species of the category $\mathrm{B}$ or $\mathrm{C}$ dominated (i.e. the $\mathrm{PME}=5$ ), the status of the ecological quality of this unit was impaired by one level.

Nomenclature of plant names is according Marhold and Hindák (1998) and categories of endangered taxa follows Feráková et al. (2001).

\section{RESULTS}

\section{Species diversity (Table 2)}

\section{6}

25 vascular aquatic macrophytes were recorded in 1996. The average number of species per survey unit was 9, with maximum 19 species registered; only one taxon was found in a ca $100 \mathrm{~m}$ long SU 12. The average species diversity was $H_{S}=2.87$ (Fig. 2). Nuphar lutea represented the dominant and Potamogeton pectinatus the sub-dominant species. Except Sagittaria sagittifolia and $P$. perfoliatus, no species reached RPM values over 6\% (Fig. 3). As to the
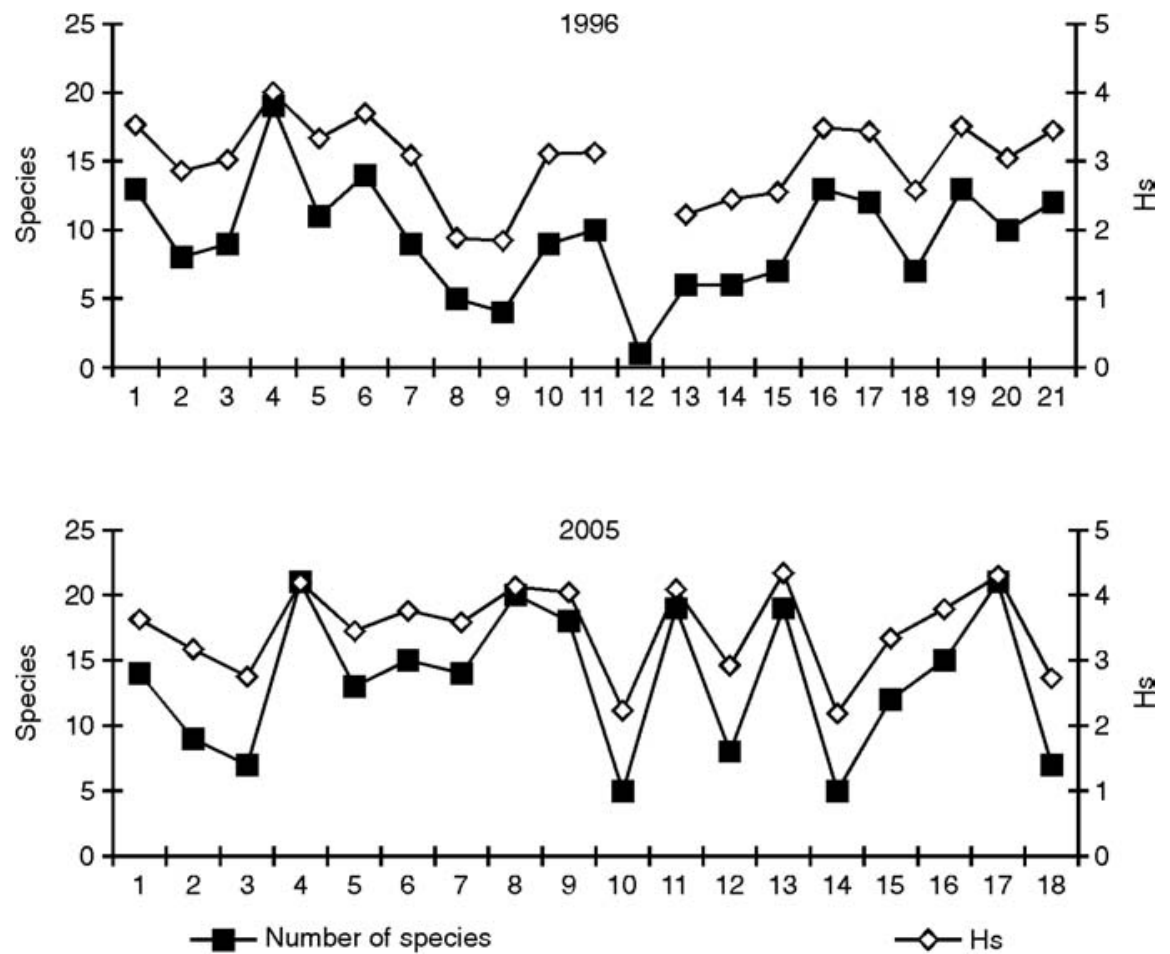

Fig. 2. The number of aquatic macrophyte species and species diversity $\left(H_{S}\right)$ in the Klátovské rameno watercourse in 1996 and 2005. 


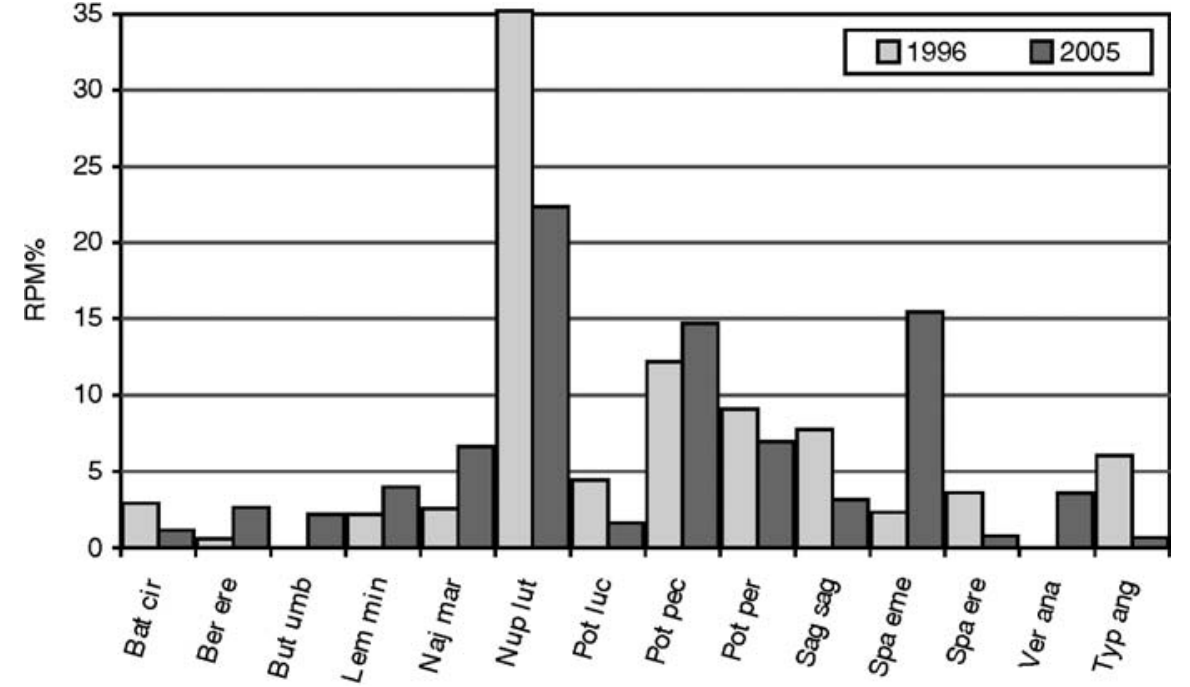

Fig. 3. Relative plant mass (RPM\%) of aquatic macrophytes in the Klátovské rameno watercourse in 1996 and 2005 (RPM>2\%).
MMT index, $N$. lutea was most abundant in the whole watercourse, followed by $P$. pectinatus, $P$. perfoliatus, and $S$. sagittifolia (Fig. 4). Several hydrophytes were ubiquitous $(\mathrm{d}>0.5)$ mainly represented by floating leaf rhizophytes such as N. lutea, and S. sagittifolia.

2005

35 aquatic macrophytes were registered during the field survey with the average number of species 13 . The number of species per unit varied from 5 to 20 with the average species diversity $H_{S}=3.48$ (Fig. 2). Nuphar lutea still dominated, although sub-dominants such as Sparganium emersum and Potamogeton pectinatus were abundant, too (Fig. 3). Relatively high values of MMT were also reached by $P$. perfoliatus and Najas marina. Lemnids were found almost throughout the whole river, but many species such as S. emersum, N. lutea, P. pectinatus, $P$. perfoliatus, Elodea canadensis, and other were ubiquitous ( $>0.5)$ as well (Fig. 4).

\section{Ecological quality (Fig. 5) \\ 1996}

In terms of the ecological status of the aquatic environment based on macrophytes, the average value of the reference index $\left(\mathrm{RI}=54.08 ; \mathrm{M}_{M P}=0.75\right)$ reflected the high status in most of the length of the watercourse $(75.5 \%)$. Good status was recorded in survey units of the upper reaches, situated in the Klátovský canal, and in the lower reaches near Trhová Hradská village, in $18.2 \%$ of the watercourse length. The moderate status was present in a unit along the banks next to the bridge.

\section{5}

The major part of the watercourse $(67.6 \%)$ was in the high ecological status according to the average value of the reference index $\left(\mathrm{RI}=53.90 ; \mathrm{M}_{M P}=0.77\right)$ based on macrophytes. A continuous stretch with high ecological status extended from the upper reaches to the vicinity of the Trhová Hradská village. In the following downstream units, the quality of aquatic environment declined, exhibiting mainly good $(25.7 \%)$ or moderate $(6.62 \%)$ ecological status.

Survey units (SU) with the worst ecological status (moderate) within studied area have a specific position in comparison with SU having a good and high ecological status
(Fig. 6). Typical eutrophic species Potamogeton pectinatus (in both years), as well as Najas marina (2005) had the strongest effect on this position.

\section{Temporal and spatial changes}

A total of 35 vascular aquatic macrophytes was found in the watercourse in 1996 and 2005. As compared with the 1996 survey the number of taxa recorded in 2005 had increased by nine species. Species diversity had raised slightly in this period (Fig. 2), the average number of species per survey unit had increased by 4 species, and the diversity by $H_{s}=0.64$.

The index of floristic similarity between 1996 and 2005 is relatively high $-I S_{s}=81.35$. The number of species common to both years was 24 . Ten aquatic macrophyte species immigrated to the channel between 1996 and 2005 (Table 2). However, the amphiphyte species could have occurred along the littoral zone in a terrestrial growth form in 1996 without being recorded. Compared to 1996, only Nymphaea alba was not recorded during our survey in 2005, nevertheless few small patches of it were registered later (Szaboóvá, verbal communication).

Nuphar lutea was the dominant species in both years of survey. No substantial changes in abundance were observed for this species. Despite a marked increase in the MMT value, that is the mean abundance over the whole river reach, of the floating leaf rhizophyte Sparganium emersum the abundance of other species such as Hydrocharis morsus-ranae, Elodea canadensis, Najas marina, Myriophyllum verticillatum, and Lemna minor increased only slightly. Conversely, the abundance of Sagittaria sagittifolia, $N$. lutea, and Hippuris vulgaris had only slightly decreased in 2005. The abundance of immigrant species was low.

The highest variability in spatial distribution was exhibited by E. canadensis (Fig. 7). In 1996, it was recorded only in the upper reaches and in a short unit near the village Trhová Hradská, whereas during the re-sampling a continuous submerged community was recorded in almost all length of the watercourse. Both S. emersum and H. morsusranae enlarged their distribution in the stream from the middle to the lower reaches during the nine-year period.

The ecological quality of the river, based on the aquatic macrophytes assessment criteria, was slightly impaired 


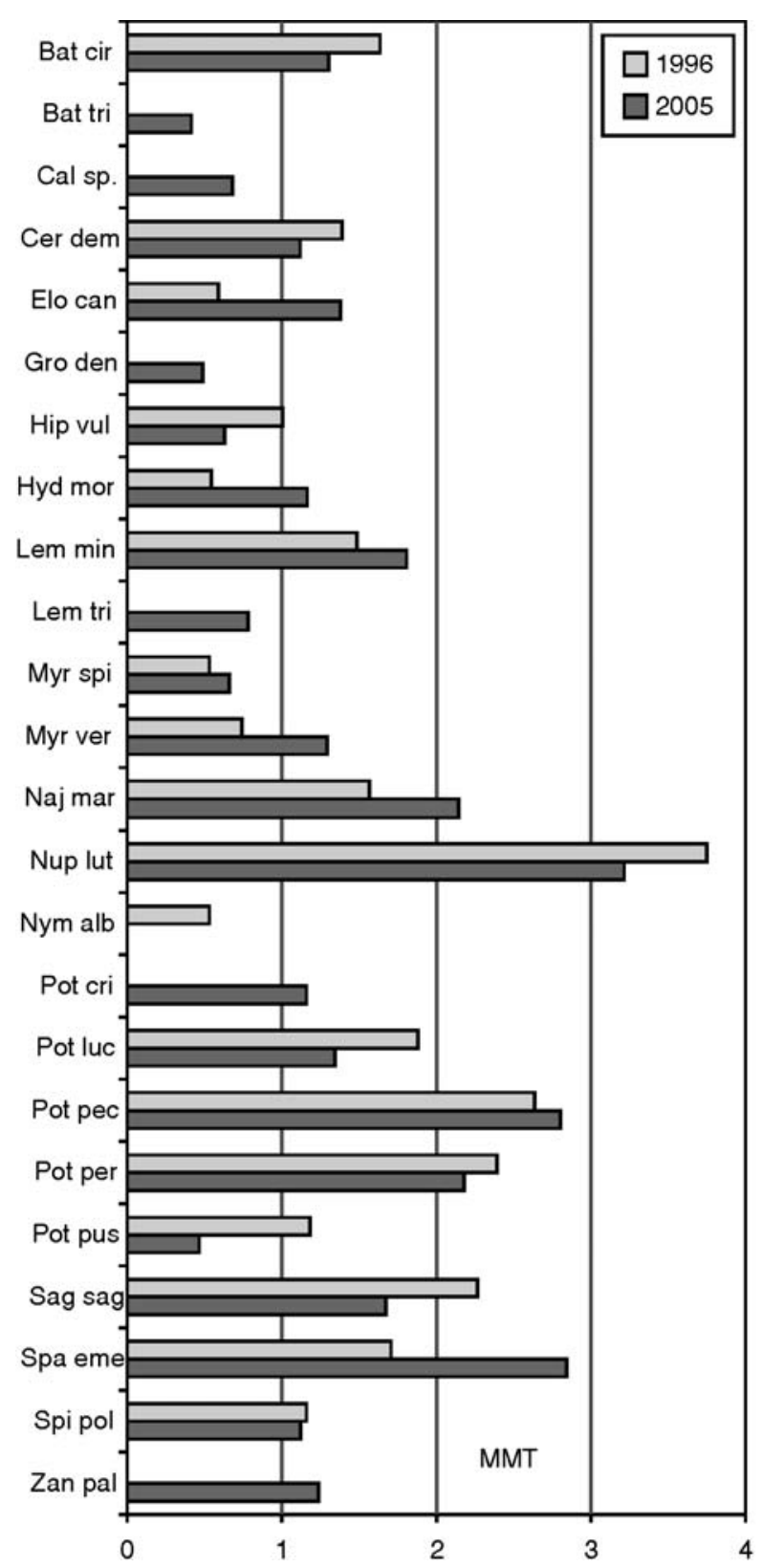

after the nine years (Fig. 7). The changes in the ratio of ecological status categories showed that $8 \%$ (ca $900 \mathrm{~m}$ ) of the river length were evaluated as "high status" in 1996, but only as "good status" in 2005 . The category of "moderate ecological status" had slightly increased.

\section{DISCUSSION AND CONCLUSIONS}

Klátovské rameno, a slow-flowing groundwater fee eutrophic river meanders naturally in the agricultural landscape of the Danube lowland. It is mainly fringed by floodplain forest and slightly modified by man in its lower reaches. The environmental conditions are excellent for development of aquatic macrophytes, which is indicated by species richness, high species diversity, and abundance. The macrophytes grow to the depth of app. $2 \mathrm{~m}$, and most species show ubiquitous distribution. The survey of aquatic macrophytes in 1996 and the re-sampling nine years later revealed the presence of 35 vascular plants. Nuphar lutea, typi-

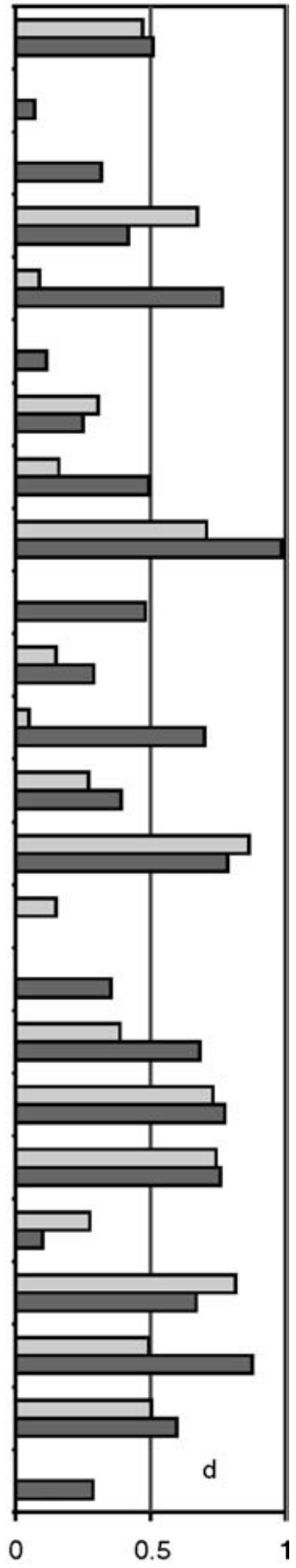

Fig. 4. Mean Mass Total index (MMT) and the distribution ratio (d) of obligatory hydrophytes in the Klátovské rameno watercourse in 1996 and 2005.

cal for the habitats of deep and slow-flowing rivers (Dawson and Szoszkiewicz 1999), remained dominant. Together with the floating leaf rhizophyte Sparganium emersum, it shaped the aspect of aquatic vegetation in a considerable length of the watercourse. Submersed anchored macrophytes, such as some species of genus Potamogeton, Myriophyllum, and Batrachium also developed large plant stands. The lack of spates or floods and the existence of microhabitats of nearly lentic environment were preferred by pleustophytes, such as lemnids, and by Hydrocharis morsus-ranae.

The changes in species abundance in a nine years period exhibited no substantial differences; however, species diversity - ten immigrated species, although with low abundance - had increased. The increased distribution of an invasive alien species Elodea canadensis confirms of disturbance in this natural ecosystem. Extended distribution and high abundance of Najas marina and Potamogeton pectinatus, the immigration of Zannichellia palustris, mainly in the settlement vicinity, are obviously a consequence of hu- 

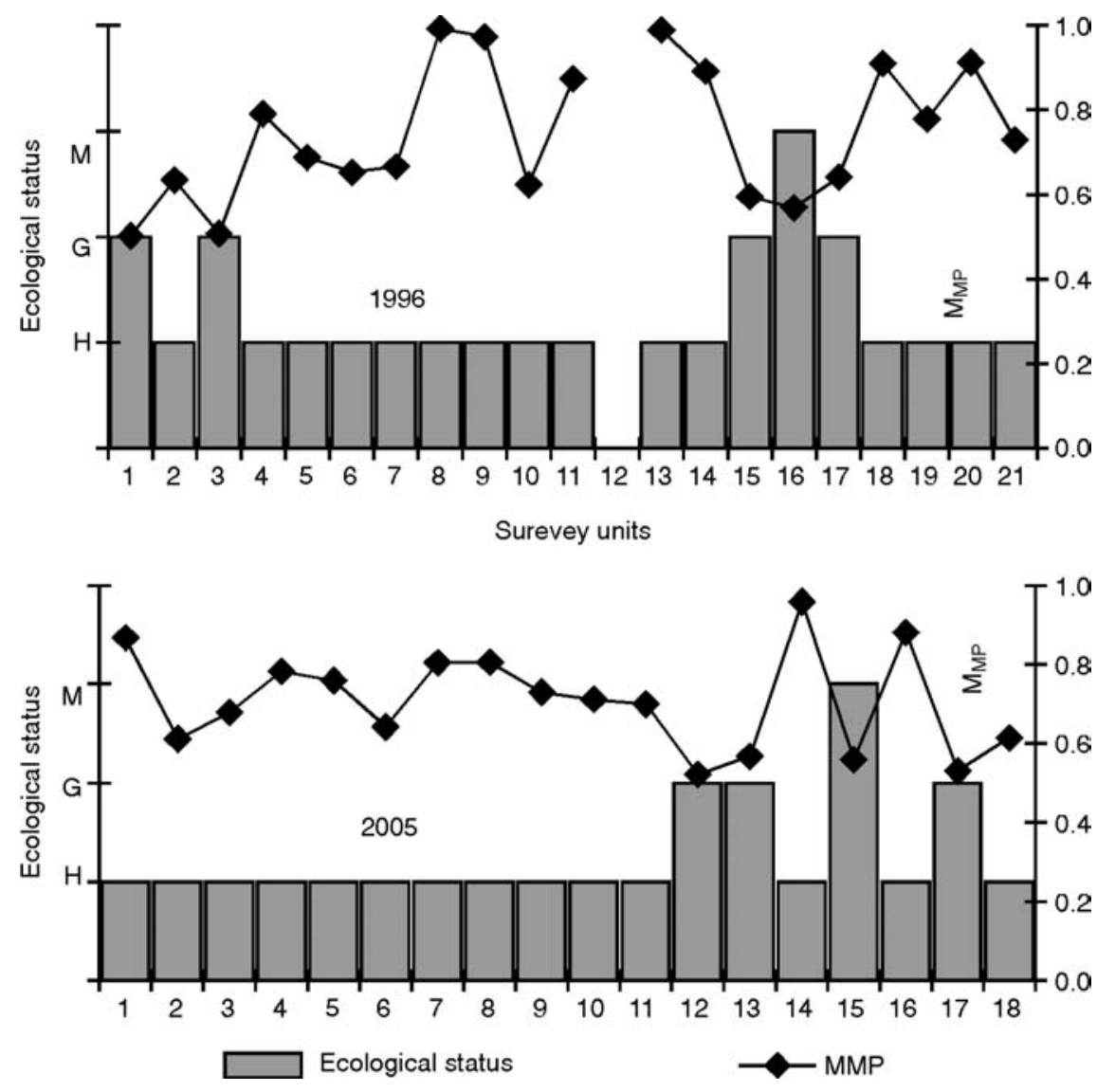

Fig. 5. The categories of ecological status ( $\mathrm{H}$ - high, $\mathrm{G}$ - good, $\mathrm{M}$ - moderate) and reference indices of macrophytes expressed as a Module macrophytes $\left(\mathrm{M}_{M P}\right)$ along the Klátovské rameno watercourse in 1996 and 2005.
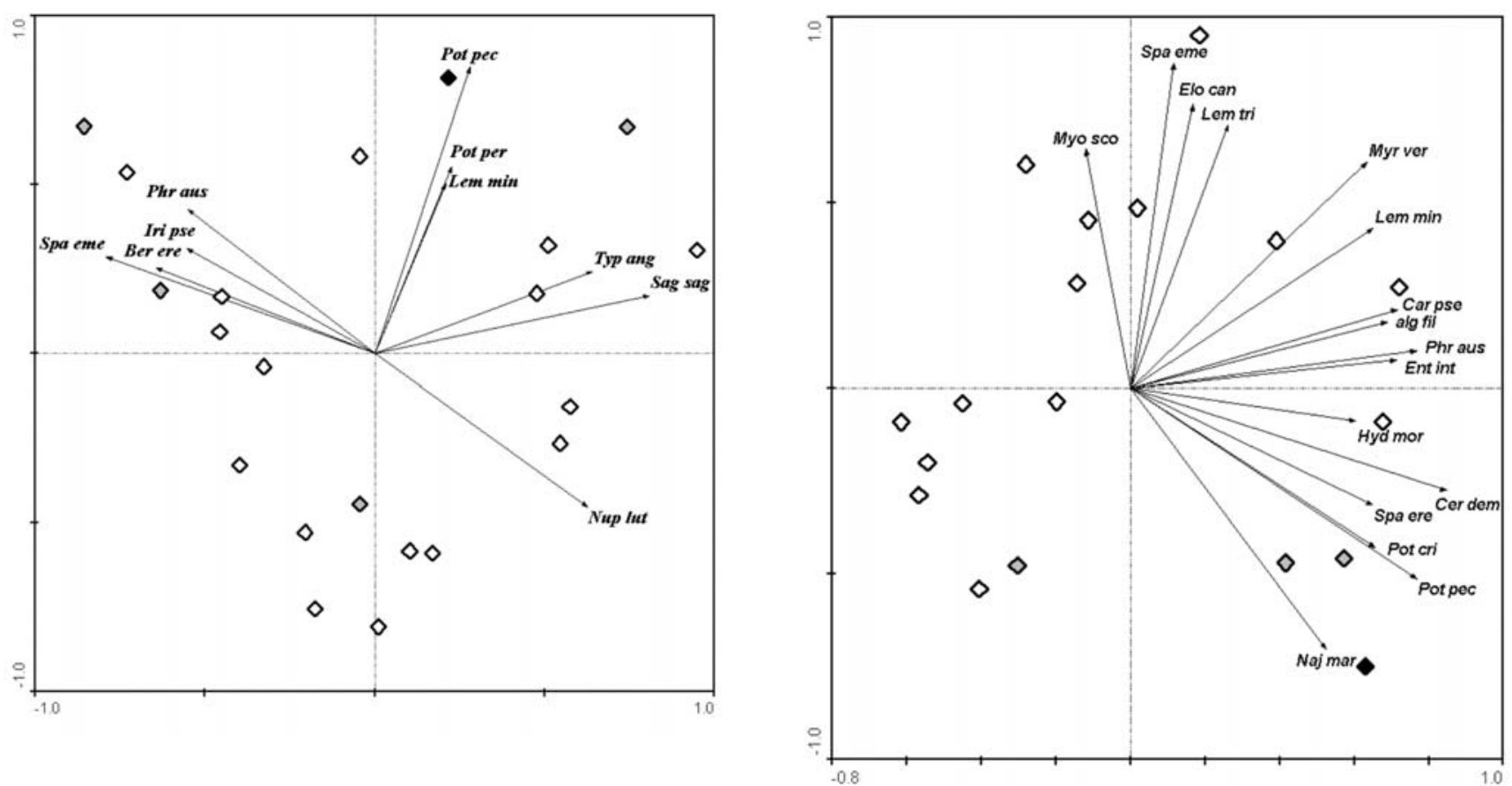

Fig. 6. PCA analysis of survey units (SU) in the Klátovské rameno stream (left figure - 1996, eigenvalues: axis 1 - 0.224, axis 2 - 0.209; right figure 2005 , eigenvalues: axis $1-0.263$, axis $2-0.234$ ). Empty diamond - SU with high ecological status, gray diamond - SU with good ecological status and black diamond - SU with moderate ecological status. Only species with score less than -0.5 , higher 0.5 and less than -0.6 , higher than 0.6 on the first two PCA axis in 1996 and 2005 are displayed, respectively.

man disturbance. The above mentioned species are generally considered as the indicators of eutrophic environment (Amoros et al. 2000; Demars and Harper 1998; Kohler and Schneider 2003; Sabbatini and Murphy 1996; Schneider and Melzer 2004). Other sources (Demars and Harper 2005) suggest, that riverbed characteristics influence plant distribution in lowland calcareous rivers, and not the water chemistry or biotic competition of filamentous algae. However, the substrate types, the depth and velocity gradients are also of great importance for the rivers of this kind (Kemp et al. 1999; Pedersen et al. 2006; Wade et al. 2002). Conversely, the macrophyte beds reduce flow velocity 

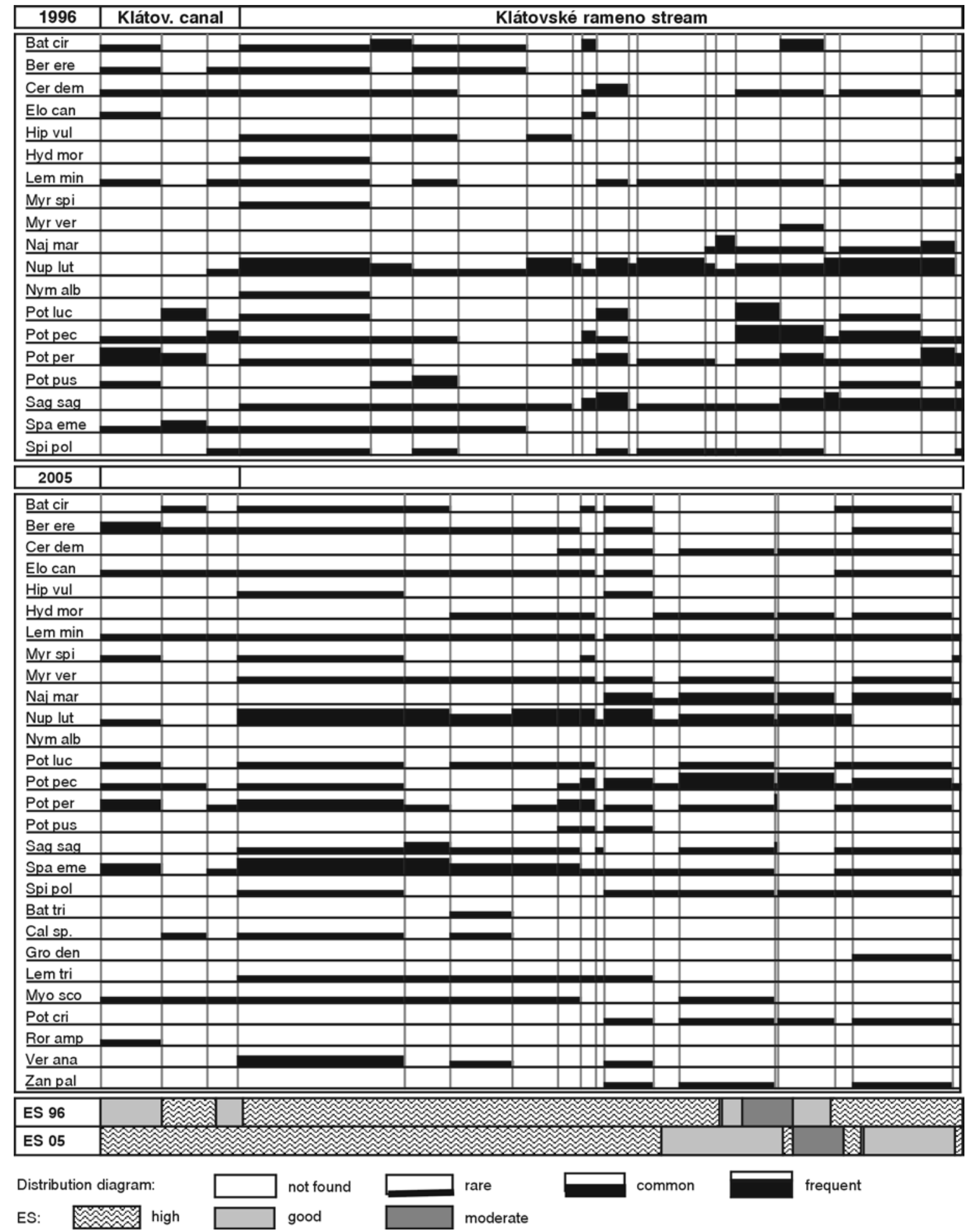

Fig. 7. The distribution diagrams of hydrophytes and the categories of ecological status (ES) along the Klátovské rameno watercourse in 1996 and 2005 (a unit length in the diagram is equivalent to its length in the watercourse).

(Champion and Tanner 2000; Sand-Jensen and Mebus 1996). In addition, the land use type reliably indicates human impact on the landscape surrounding the river corridor (Janauer and Exler 2004). Our survey confirmed a direct influence of changes in these patterns on the taxonomic composition and abundance of aquatic macrophytes reflected in the ecological quality of surveyed watercourse.

Noticeable changes in the aquatic vegetation structure of the Klátovské rameno stream, strengthened by the anthro- pic impact, were recorded in survey units near the settlements. There were observed visible changes in the bankmorphology structure, reflected predominantly in the depth of fine sediments. The studied stream is naturally rich in nutrients. As hydro-chemical data were not available in our study, we are unable to assess the importance of this source of disturbance directly. However, we assume that an increased supply of nutrients is possible. The development of methods for the assessment of ecological integrity of run- 
ning waters requires integrating physical and chemical parameters, as well as their effects upon biological structure, diversity, and processes (Harper et al. 2000).

The patterns of aquatic vegetation are generally similar along the Danube River course being nearly equal in systems of arms and alluvial water-bodies from Germany to the Danube Delta (Cristofor et al. 2003; Germ et al. 2003; Hrivnák 2002a, b; Jursa and Ot’ahelová 2005; Janauer and Pall 2003; Pall et al. 1996; Rath et al. 2003; Sarbu 2003; Vukov et al. 2004). These habitats are of special importance also for the occurrence of numerous endangered and rare species. In the Klátovské rameno stream, which is under the conservation measures in the framework of the NNR and the NATURA 2000, ten endangered aquatic species were recorded (Table 2).

The WFD requires the assessment of the ecological status and monitoring the surface water-bodies through biological indicators. Based on floristic composition and abundance of aquatic macrophytes and near natural bank-morphology of the stream, we consider some parts of the Klátovské rameno stream to be, in a WFD sense, a suitable reference site of the lowland slow-flowing groundwater fed eutrophic running waters in Slovakia. Localities like the Klátovské rameno stream deserve taking benefits from joint legislation of the EU Water Framework Directive and the EU Habitats Directive (92/43/EEC).

\section{ACKNOWLEDGEMENTS}

This study is a part of the VEGA 5083 project from the Grant Agency of Slovak Academy of Sciences and the Ministry of Education. The on-line data processing, we are thankful for, was accomplished in the framework of the MIDCC project of the Austrian Federal Ministry of Education, Science, and Culture. We are especially grateful to T. Kičinová for carrying out most of the fieldwork in 1996 and to N. Jegorová for the assistance with translation.

\section{LITERATURE CITED}

AMOROS C., BORNETTE G., HENRY C.P. 2000. A vegetation based method for ecological diagnosis of riverine wetlands. Environmental Management 25: 211-227.

BAATTRUP-PEDERSEN A., RIIS T. 1999. Macrophyte diversity and composition in relation to substratum characteristics in regulated and unregulated Danish streams. Freshwater Biology 42: 375-385.

Council Directive 92/43/EECC of 21 May 1992 on the Conservation of Natural Habitats and Wild Fauna and Flora. Official Journal L 206, 22.07.1992 P, 0007-0050.

BERNEZ I., DANIEL H., HAURY J., FERREIRA M.T. 2004. Combined effects of environmental factors and regulation on macrophyte vegetation along three rivers in Western France. River Res. Applic. 20: 43-59.

CHAMPION P.D., TANNER C.C. 2000. Seasonality of macrophytes and interaction with flow in a New Zealand lowland stream. Hydrobiol. 441: 1-12.

CRISTOFOR S., VADINEANU A., SARBU A., POSTOLACHE C., DOBRE R., ADAMESCU M. 2003. Long-term changes of submerged macrophytes in the Lower Danube Wetland System. Hydrobiol. 506-509: 625-634.

DAWSON F.H., SZOSZKIEWICZ K. 1999. Relationships of some ecological factors with the associations of vegetation in British rivers. Hydrobiol., 415: 117-122.
DEMARS B.O.L., HARPER D.M. 1998. The aquatic macrophytes of an English lowland river system: assessing response to nutrient enrichment. Hydrobiol. 384: 75-88.

DEMARS B.O.L., HARPER D.M. 2005. Distribution of aquatic vascular plants in lowland rivers: separating the effects of local environmental conditions, longitudinal connectivity and river basin isolation. Freshw. Biol. 50: 418-437.

DODKINS I., RIPPEY B., HALEP P. 2005. An application of canonical correspondence analysis for developing ecological quality assessment metrics for river macrophytes. Freshw. Biol. 50: 891-904.

FERÁKOVÁ V., MAGLOCKÝ Š., MARHOLD K. 2001. Červený zoznam paprad’orastov a semenných rastlín Slovenska (December 2001). Ochr. Prír. 20: 44-77. Red list of ferns and flowering plants of Slovakia (December 2001) (in Slovak with English summary)

GERM M., DOLINŠEK M., GABERŠČIK A. 2003. Macrophytes of the River Ižica - comparison of species composition and abundance in the years 1996 and 2000. Arch. Hydrobiol., Suppl. 147 (1-2), Large Rivers 14 (1-2): 181-194.

HARPER D.M., KEMP J.K., VOGEL B., NEWSON M.D. 2000. Towards the assessment of 'ecological integrity' in running waters of the United Kingdom. Hydrobiol. 422/423: 133-142.

HASLAM S.M. 1978. River Plants.The macrophytic vegetation of water courses. Cambridge University Press, London, 396 pp.

HOLČÍK J. 2004. Ryby a rybárstvo v NPR Klátovské rameno. Ochr. Prír. 23: 265-275. Fish and fishery in the National Nature Reserve Klátovské rameno. (in Slovak with English summary)

HRIVNÁK R. 2002a. Aquatic plant communities in the catchment area of the Ipel river in Slovakia and Hungary. Part I. Classes Lemnetea and Charetea fragilis. Thaiszia - J. Bot., Košice 12: 25-50.

HRIVNÁK R. 2002b. Aquatic plant communities in the catchment area of the Ipel river in Slovakia and Hungary. Part II. Class Potametea. Thaiszia - J. Bot. Košice 12:137-160.

HRIVNÁK R., VALACHOVIČ M., RIPKA J. 2003. Relation between macrophyte vegetation and environmental conditions in the Ipel River (Slovakia) - case study. Arch. Hydrobiol. Suppl. 147 (1-2), Large Rivers 14 (1-2): 117-127.

HRIVNÁK R., VALACHOVIČ M., RIPKA J. 2004. Ecological conditions in the Turiec River (Slovakia) and their influences on the distribution of aquatic macrophytes. Limnol. Rep. 35: 449-455.

JANAUER G.A. 2003. Methods. Arch. Hydrobiol. Suppl. 147 (1-2), Large Rivers 14 (1-2): 9-16.

JANAUER G.A., EXLER N. 2004. Distribution and habitat conditions of the six most frequent hydrophytes in the Danube River corridor: status 2002. Limnol. Rep. 35: 407-411.

JANAUER G.A., PALL K. 2003. Impoundment AbwindenAsten, Austria (river-km 2136-2119.5): species distribution features and aspect of historical status. Arch. Hydrobiol., Suppl. 147 (1-2), Large Rivers 14 (1-2): 87-196.

JURSA M., OŤAHELOVÁ H. 2005. Distribution of aquatic macrophytes in man-modified water-bodies of the Danube River in Bratislava region (Slovakia). Ekológia 24: 368-384.

KEMP J.L., HARPER D.M., CROSA G.A. 1999. Use of 'functional habitats' to link ecology with morphology and hydrology in river rehabilitation. Aquatic Conservation: Marine and Freshw. Ecosyst. 9: 159-178.

KOHLER A. 1978. Methoden der Kartierung von Flora und Vegetation von Süßwasserbiotopen. Landschaft+ Stadt 10 (2): 23-85.

KOHLER A., JANAUER G.A. 1995. Zur Methodik der Untersuchungen von aquatischen Makrophyten in Fließgewässern. In: Steinberg, C., Bernhardt H., Klapper H. (eds). Handbuch Angewandte Limnologie. pp. 1-22. Ecomed Verlag, Lansberg/Lech.

KOHLER A., SCHNEIDER S. 2003. Macrophytes as bioindicators. Arch. Hydrobiol. Suppl. 147 (1-2), Large Rivers 14 (1-2): 17-32. 
LAPIN M., FAŠKO P., MELO M., ŠŤASTNÝ P., TOMLAIN J. 2002. Klimatické oblasti. (1:1 000 000) p. 95. In: Miklós L. (ed.), Atlas krajiny Slovenskej republiky, Ministerstvo životného prostredia SR, Bratislava \& Slovenská agentúra životného prostredia, Banská Bystrica, 344 pp. Climatic regions. (1:1 000 000). In: Miklós L. (ed.), Landscape Atlas of the Slovak Republic. (in Slovak with English summary)

MARHOLD K., HINDÁK F. 1998. Checklist of non-vascular and vascular Plants of Slovakia. Veda, Bratislava, $687 \mathrm{pp}$.

MEILINGER P., SCHNEIDER S., MELZER A. 2005. The Reference Index Method for the Macrophyte-Based Assessment of Rivers - a Contribution to the Implementation of the European Water Framework Directive in Germany. Internat. - Rev. Hydrobiol. 90 (3): 322-342.

MICHALKO J., MAGIC D., BERTA J., RYBNÍČEK K., RYBNÍČKOVÁ E. 1987. Geobotanical map of Č.S.S.R. Veda, Bratislava, $167 \mathrm{pp}$.

ONAINDIA M., AMEZAGA I., GARBISU C., GARCÍA-BIKUNA B. 2005. Aquatic macrophytes as biological indicators of environmental conditions of rivers in north-eastern Spain. Ann. Limnol.-Int. J. Lim. 41 (3): 175-182.

OŤAHELOVÁ H. 1995a. Lemnetea de Bolós et Masclans 1955. In: Valachovič M. (ed.), Rastlinné spoločenstvá Slovenska 1. Pionierska vegetácia, p. 129-150. Veda, Bratislava. (in Slovak)

OŤAHELová H. 1995b. Potametea R. Tx. et Preising 1942. In: Valachovič M. (ed.), Rastlinné spoločenstvá Slovenska 1. Pionierska vegetácia, p. 151-179. Veda, Bratislava. (in Slovak)

OŤAHELOVÁ H., BANÁSOVÁ V. 2005. The response of aquatic macrophytes to restoration management in the Morava River oxbows. Biologia, Bratislava 60: 403-408.

OŤAHEL'OVÁ H., HRIVNÁK R., VALACHOVIČ M. 2001. Phragmito-Magnocaricetea Klika in Klika et Novák 1941. pp. 51-183. In: Valachovič M. (ed.), Rastlinné spoločenstvá Slovenska 3. Vegetácia mokradí. Veda, Bratislava. 435 pp. Plant communities of Slovakia 3. Wetland Vegetation. (in Slovak with English summary)

OŤAHELOVÁ H., VALACHOVIČ M. 2003. Distribution of macrophytes in different water-bodies (habitats) influenced by the Gabčíkovo hydropower station (Slovakia) - present status. Arch. Hydrobiol., Suppl. 147 (1-2), Large Rivers 14 (1-2): 97-115.

PALL K., RATH B., JANAUER G.A. 1996. Die Makrophyten in dynamischen und abgedämmten Gewässersystemen der Kleinen Schüttinsel (Donau Fluß-km 1848 bis 1806). Limnologica 26 (1): 105-115.

PEDERSEN T.C.M., BAATTRUP-PEDERSEN A., MADSEN T.V. 2006. Effects of stream restoration and management on plant communities in lowland streams. Freshw. Biol., 51: 161-179.

PIŠÚT P., KUBALOVÁ S., HAJNALOVÁ M., SLAMKOVÁ M. 2004. Study of the Danube River Paleochannel, Slovakia (Preliminary results). Geomorphologia Slovaca 1: 12-21.

RATH B., JANAUER G.A., PALL K., BERCZIK A. 2003. The aquatic macrophyte vegetation in the Old Danube/Hungarian bank, and other water bodies of the Szigetköz wetlands. Arch. Hydrobiol., Suppl. 147 (1-2), Large Rivers 14 (1-2): 129-142.

ROBACH F., THIÉBAUT G., TRÉMOLIE'RES M., MULLER S. 1996. A reference system for continental running waters: plant communities as bioindicators of increasing eutrophication in alkaline and acidic water in northeast France. Hydrobiol. 340: 67-76.

SABBATINI M.R., MURPHY K.J. 1996. Submerged plant survival strategies in relation to management and environmental pressures in drainage channel habitat. Hydrobiol. 340: 191-195.

SAND-JENSEN K., MEBUS J.R. 1996. Fine-scale patterns of water velocity within macrophyte patches in streams. Oikos 76: $169-180$.

SARBU A. 2003. Inventory of aquatic plants in the Danube Delta: a pilot study in Romania. Arch. Hydrobiol., Suppl. 147 (1-2), Large Rivers 14 (1-2): 205-216.

SCHAUMBURG J., SCHRANZ C., FOERSTER J., GUTOWSKI A., HOFMANN G., MEILINGER P., SCHNEIDER S., SCHMEDTJE U. 2004. Ecological classification of macrophytes and phytobenthos for rivers in Germany according to the Water Framework Directive. Limnologica 34: 283-301.

SCHNEIDER S., MELZER A. 2004. Sediment and water nutrient characteristics in patches of submerged macrophytes in running waters. Hydrobiol. 527: 195-207.

SØRENSEN T. 1948. A method of establishing groups of equal amplitude in plant society based on similarity of species content. K. Danske Vidensk. Selsk. 5: 1-34.

SZABÓOVÁ A., BANKÓ Z. 2004. Groenlandia densa (L.) Foyer. - nový výskyt na Slovensku. Chránené územia Slovenska 59: 19-20. (in Slovak)

ŠIMO E., ZAŤKO M. 2002. Typy režimu odtoku. (1:2 000 000) p. 103. In: Miklós L. (ed), Atlas krajiny Slovenskej republiky, Ministerstvo životného prostredia SR, Bratislava \& Slovenská agentúra životného prostredia, Banská Bystrica, 344 pp. Types of runoff regime. (1:2 000 000). In: Miklós L. (ed.), Landscape Atlas of the Slovak Republic. (in Slovak with English summary)

TER BRAAK C.J.F., ŠMILAUER P. 2002. CANOCO Reference manual and CanoDraw for Windows User's guide. Software for Canonical Community Ordination (version 4.5). Ithaca, NY: Microcomputer Power.

THIEBAUT G., MULLER S. 1999. A macrophyte communities sequence as an indicator of eutrophication and acidification levels in weakly mineralised streams in north-eastern France. Hydrobiol. 410: 17-24.

VUKOV D., ANAČKOV G., IGIC R., JANAUER G.A. 2004. The Aquatic macrophytes of "Mali Derdap" (Danube, rkm 1039-999). Limnol. Rep. 35: 421-426.

WADE A.J., WHITEHEAD P.G., HORNBERGER G.M., SNOOK D.L. 2002. On modelling the flow controls on macrophyte and epiphyte dynamics in a lowland permeable catchment: the River Kennet, southern England. The Science of the Total Environment 282-283: 375-393.

WHITTAKER R.H. 1972. Evolution and measurements of species diversity. Taxon 21: 213-251.

WFD 2000. Directive 2000/60/EC of the European parliament and of the council establishing a framework for community action in the field of water policy. Brussels. $72 \mathrm{pp}$.

WIEGLEB G. 1981. Struktur, Verbreitung und Bewertung von Makrophytengesellschaften niedersächsischer Fließgewässer. Limnologica 13: 427-448. 